\title{
Extract of Ascaris suum induces TGF- $\beta$ and early production of IgG1 in experimental autoimmune hepatitis
}

\author{
Extrato de Ascaris suum induz TGF- $\beta$ e produção precoce de IgG1 na hepatite \\ autoimune experimental
}

\begin{abstract}
Roeckson Carlos Peixoto Silva ${ }^{1,2}$; Raul Penaforte Correia da Silva',2;
Maria da Conceição Silva ${ }^{1,2}$; Wheverton Ricardo Correia do Nascimento2; Vlaudia Maria Assis Costa ${ }^{1,2}$; Mônica Camelo Pessôa de Azevedo Albuquerque ${ }^{1,2}$; Valdênia Maria Oliveira de Souza ${ }^{1,3 *}$ (i)

'Laboratório de Imunopatologia Keizo Asami, Universidade Federal de Pernambuco - UFPE, Recife, PE, Brasil ${ }^{2}$ Departamento de Medicina Tropical, Universidade Federal de Pernambuco - UFPE, Recife, PE, Brasil

${ }^{3}$ Departamento de Ciências Farmacêuticas, Universidade Federal de Pernambuco - UFPE, Recife, PE, Brasil
\end{abstract}

How to cite: Silva RCP, Silva RPC, Silva MC, Nascimento WRC, Costa VMA, Albuquerque MCPA, et al. Extract of Ascaris suum induces TGF- $\beta$ and early production of IgG1 in experimental autoimmune hepatitis. Braz J Vet Parasitol 2020; 29 (2): e023419. https://doi.org/10.1590/S1984-29612020031

\begin{abstract}
In experimental autoimmune hepatitis (EAH) of Th1 profile, an extract of adult Ascaris suum worms (ASC) was previously found to deviate the immune response to a Th2/IL-10 pattern. Here, the effects of treatment with ASC on production of TGF- $\beta$ and the anti-Ascaris isotypes IgG1 and IgG2a in EAH were evaluated. EAH was induced in $\mathrm{BALB} / \mathrm{c}$ mice, intravenously with concanavalin A. Two hours later, these animals received ASC (EAH+ASC group) or PBS vehicle (EAH group). IgG1 and IgG2a were evaluated $8 \mathrm{~h}, 24 \mathrm{~h}$ and $7 \mathrm{~d}$ after induction. TGF- $\beta$ was measured in a splenocyte culture at this last time. The isotype levels in the EAH group were low throughout the kinetics. In the EAH+ASC group, there was significant production of IgG1 at $24 \mathrm{~h}$ and $7 \mathrm{~d}$, but of IgG2a only at $7 \mathrm{~d}$. There was statistically greater production of TGF- $\beta$ in the EAH+ASC group. The higher levels of IgG1 and TGF- $\beta$ in this group suggest that an additional Th1 response control route exists in $\mathrm{EAH}$, which needs to be investigated.
\end{abstract}

Keywords: Ascaris suum, experimental autoimmune hepatites, immunomodulation.

\section{Resumo}

Na hepatite autoimune experimental (HAE) de perfil Th1, o extrato de vermes adultos Ascaris suum (ASC) desviou a resposta imune para um padrão Th2/IL-10. Neste trabalho, foram avaliados os efeitos do tratamento com ASC na produção TGF- $\beta$ e dos isótipos de IgG1 e IgG2a anti-Ascaris na HAE. Esta foi induzida em camundongos BALB/c intravenosamente com Concanavalina A. Após duas horas, os animais receberam ASC (grupo HAE+ASC) ou veículo PBS (grupo HAE). IgG1 e IgG2a foram avaliados em 8 horas, 24 horas e 7 dias após indução. TGF- $\beta$ foi mensurado em cultura de esplenócitos nesse último tempo. Os níveis dos isótipos no grupo HAE foram baixos durante toda a cinética. No grupo HAE+ASC, houve produção significativa de IgG1 em 24 horas e 7 dias, mas somente em 7 dias para IgG2a. A produção de TGF- $\beta$ foi estatisticamente maior no grupo HAE+ASC. Níveis mais altos de IgG1 e TGF- $\beta$ nesse grupo sugerem uma via adicional de controle da resposta Th1 na HAE que precisa ser investigada.

Palavras-chave: Ascaris suum, hepatite autoimune experimental, imunomodulação. 


\section{Introduction}

An extract of adult Ascaris suum worms (ASC) has been found to suppress the inflammatory response to heterologous antigens through mechanisms that depend on IL-10/TGF- $\beta$ and CD4+CD25+Foxp3 ${ }^{+}$T cells (Araújo et al., 2010; Souza et al., 2002). In experimental autoimmune hepatitis (EAH), it has been demonstrated that ASC has a protective effect through promoting increased levels of IL-4, IL-10 and IL-13, accompanied by reduction of inflammatory infiltrate and restoration of transaminases (Nascimento et al., 2014). However, the levels of TGF- $\beta$ and anti-Ascaris IgG isotypes in this inflammation model were not evaluated.

ASC induced Th2 response that was correlated with the in vivo suppression, IL-4 and IL-10 synthesis (Ferreira et al., 1995). Immunization with PAS-1, a protein of $A$. suum, stimulated the Th2 response, production of IL-10 and TGF- $\beta$ in allergic airway inflammation induced by OVA in mice (Araújo et al., 2010). Regarding IgG subclasses, immunization with extract of adult worms, larvae or worm cuticle of $A$. suum confers protective immunity against infection induced by anti-Ascaris antibodies of the subclasses IgG1 and IgG3 (Gazzinelli-Guimarães et al., 2018). Immunization with As16, a protein genetically related to $A$. suum, also induces a predominantly Th2 response, with high serological titers of IgG1 (Wei et al., 2017). It is known that IgG isotypes activate macrophages that produce IL-10, thus impairing the Th1 response (Buxbaum \& Scott, 2005). It is possible that ASC may help in controlling the autoimmune inflammatory process through inducing a suppressive profile via IgG1/IL-10 and TGF- $\beta$. Although it is known that treatment with ASC causes negative modulation of immunopathology in EAH, with development of an immune response of Th2 profile, evaluation of other modulation routes becomes necessary.

\section{Materials and Methods}

\section{Animals, Ascaris suum extract and concanavalin A}

Eight-week-old male BALB/c mice were housed in the animal care facility at the Keizo Asami Immunopathology Laboratory, Federal University of Pernambuco (LIKA/UFPE). Extract of adult $A$. suum worms was obtained in according to Souza et al. (2002). Concanavalin A type IV (ConA) (Sigma-Aldrich, St. Louis, MO, USA) was diluted in sterile $0.01 \mathrm{M}$ PBS at pH 7.2.

\section{Experimental groups}

Three experimental groups were formed (6 animals/group). EAH was induced in the mice by intravenously administering $20 \mathrm{mg} / \mathrm{kg}$ of ConA diluted in sterile PBS $(2 \mathrm{mg} / \mathrm{mL})$. After two hours, some of these animals received PBS (i.p.) (EAH group) and the remainder of the animals received $1 \mathrm{mg}$ of ASC (i.p.) (EAH+ASC group). The control animals received only PBS (control group). The experimental model and hepatitis parameters were adjusted as described by Nascimento et al. (2014). This protocol was approved by the Ethics Committee of the Biological Sciences Research Center, UFPE (no. 23076.041797/2013-40).

\section{Detection of anti-Ascaris antibodies using ELISA}

Blood samples were collected $8 \mathrm{~h}, 24 \mathrm{~h}$ and 7 days after induction of EAH. Ascaris-specific IgG1 and IgG2a antibodies were titrated using ASC (5 $\mu \mathrm{g} / \mathrm{mL}$ )-coated 96-well plates (Nunc MaxiSorp, Denmark) and biotinylated goat anti-mouse IgG1 or IgG2a (Southern Biotechnology Associates Inc, USA). The reactions were developed using a streptavidin-HRP conjugate (Sigma-Aldrich, USA) and an O-phenylenediamine (Sigma-Aldrich, USA) solution in $0.1 \mathrm{M}$ citrate buffer plus $\mathrm{H}_{2} \mathrm{O}_{2}$. The plates were read in $450 \mathrm{~nm}$. The results were expressed as the mean of optical density \pm standard deviation at a dilution corresponding to the linear part of the titration curve $(1: 10)$.

\section{Culturing of spleen cells and TGF- $\beta$ measurement using ELISA}

Seven days after induction of EAH, the spleens of the mice in the EAH and EAH+ASC groups were harvested. Cell suspensions were prepared as described by Nascimento et al. (2014) and the supernatants were harvested (72h) and assayed for TGF- $\beta$ content using a commercial kit (Invitrogen, Novex, USA). 


\section{Statistical analysis}

For antibody production analysis, the two-way ANOVA test was used to evaluate the differences among groups. Multiple comparisons were performed using the Bonferroni test. For TGF- $\beta$ production analysis, the t test was used. For statistical analyses, we used GraphPad Prism 5.0 (GraphPad Software, San Diego, USA), and all findings were considered significant at $p<0.05$. All the procedures were repeated three times to evaluate the reproducibility of the results, and one representative of the three independent analyses was presented.

\section{Results}

In the EAH group, the levels of anti-Ascaris IgG1 and IgG2a were extremely low and followed the same kinetics, with much lower levels at $24 \mathrm{~h}$. In the EAH+ASC group, production of IgG2a only occurred at the $7^{\text {th }}$ day and was at higher levels than in the EAH group. Regarding anti-Ascaris IgG1, production occurred at $8 \mathrm{~h}, 24 \mathrm{~h}$ and the $7^{\text {th }}$ day, but was significantly greater at the latter two times (Figure 1A), in relation to EAH group. In the control group, there were no detection of anti-Ascaris antibodies (data not shown).

TGF- $\beta$ was measured in the supernatant from culturing of splenocytes only with medium and stimulated with ConA or ASC. Under these conditions, the TGF- $\beta$ production was greater in the EAH+ASC group than in the EAH group (Figure 1B).
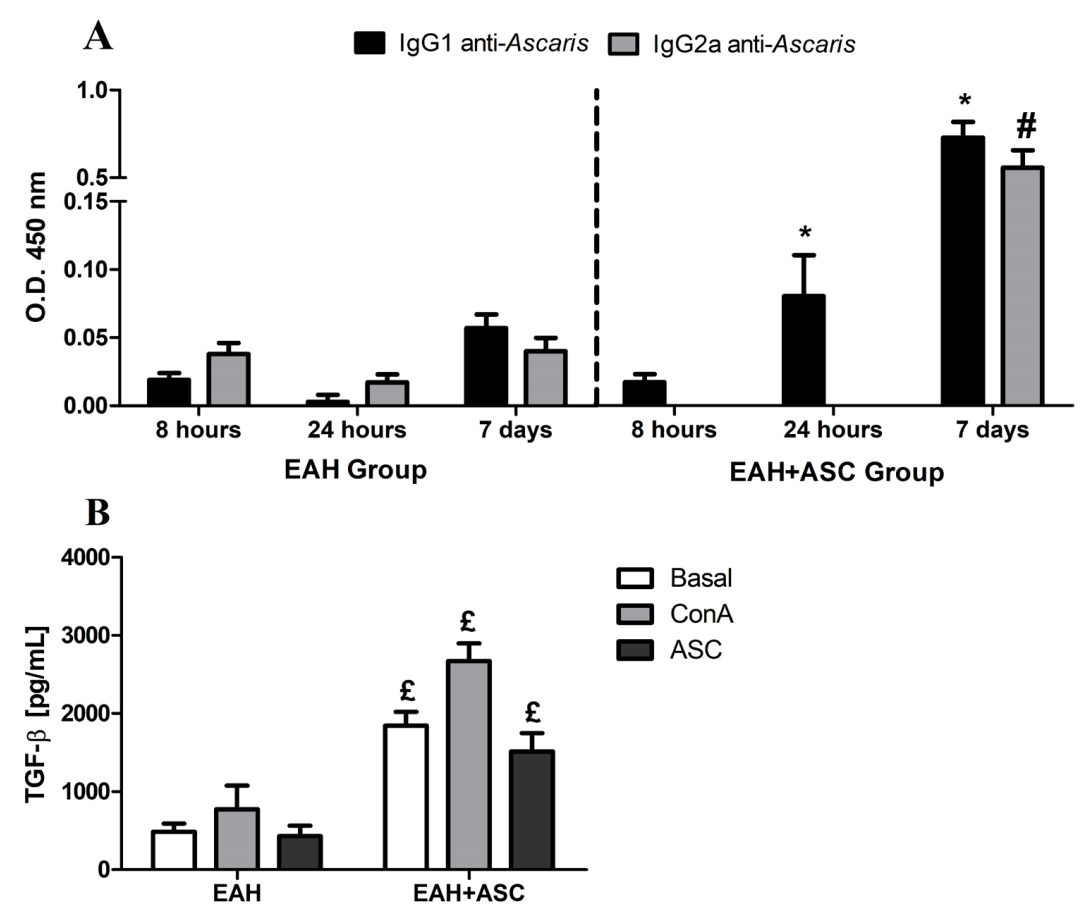

Figure 1. Anti-Ascaris IgG1 and IgG2a isotypes (A) in the plasma of BALB/c mice, 8 h, $24 \mathrm{~h}$ and 7 days after induction of experimental autoimmune hepatitis (EAH) and treatment with a soluble extract $A$ scaris suum worms (ASC), by ELISA. TGF- $\beta$ levels (B) in cultures of splenocytes from the EAH and EAH+ASC groups ( $\left.72 \mathrm{~h} ; 6 \times 10^{6} \mathrm{cells} / \mathrm{mL}\right), 7$ days after induction of EAH, that were cultured only with medium (Baseline), ConA $(10 \mathrm{ng} / \mathrm{mL})$ or ASC $(20 \mu \mathrm{g} / \mathrm{mL})$. The results are presented as the mean \pm standard deviation of 6 animals/group. ${ }^{*} p<0.05$ in relation to the EAH group for $\operatorname{lgG} 1 ; \# p<0.05$ in relation to the EAH group for IgG2a; $£ p<0.05$ in relation to the EAH group for TGF- $\beta$.

\section{Discussion}

Administration of an extract of $A$. suum was previously found to attenuate the hepatic damage in EAH through deviating the Th1 immune response to a Th2/IL-10 pattern (Nascimento et al., 2014). Here, it was possible to demonstrate that treatment with ASC induced elevated levels of TGF- $\beta$ and anti-Ascaris IgG1 and IgG2a, although IgG1 was produced earlier and at higher levels. 
In the EAH group, production of specific anti-Ascaris antibodies was observed. This can be explained by the administration of ConA. It gives rise to polyclonal expansion of $\mathrm{T}$ lymphocytes and consequently, B lymphocytes (Tiegs et al., 1992). In the EAH+ASC group, the kinetics of production of the IgG1 and IgG2a isotypes were distinct. Production of the IgG2a isotype was only detected at the $7^{\text {th }}$ day. On the other hand, production of $\operatorname{lgG} 1$ already occurred at higher levels at $24 \mathrm{~h}$ and was also seen at the $7^{\text {th }}$ day. This result corroborates the previous description of redirecting of the immune response in EAH caused by ASC, to a Th2 profile, within the first 24 hours. It is known the IgG1 class-switching IL-4 and Asc-dependent (Silva et al., 2006). Indeed, the production of the IgG1 began together with higher levels of IL-4 and IL-13 (Nascimento et al., 2014).

The relationship between IgG-FcyR and IL-10 synthesis via macrophages is known in experimental parasite model (Buxbaum \& Scott, 2005; Fairfax et al., 2012). Helminth antigen induced a hepatic microenvironment with high levels of IL-4 and IL-13 may promote differentiation of macrophages that produce IL-10, named M2 that are relevant in the tissue repair (Rolot \& Dewals, 2018). In EAH, ASC caused increases in IL-4, IL-10 and IL-13 levels (Nascimento et al., 2014). IL-10 is crucial for tolerance induction in EAH (Erhardt et al., 2007). It is possible that deviation of production of IgG isotype to the subclass IgG1, in response to ASC, may be negatively modulating the lesion in EAH through induction of IL-10 by macrophages at an early stage ( $24 \mathrm{~h})$. Tests using FcyR knockout mice might help to confirm this hypothesis.

In addition to production of IL-10 via IgG1, it is possible that the suppression mediated by ASC in EAH may also occur through induction of TGF- $\beta$. Blockage of TGF- $\beta$ suppresses the functioning of CD4 ${ }^{+} C D 25^{+} F o x p 3^{+}$T lymphocytes, thus making mice more susceptible to EAH (Wei et al., 2008). Here, treatment with ASC induced elevated levels of TGF- $\beta$. However, inflammatory cytokines (IL-17, IL-22) deserve to be studied.

\section{Conclusions}

In conclusion, higher levels of IgG1 and TGF- $\beta$ may indicate control over the Th1 response during EAH. However, further studies are needed to confirm this hypothesis. Comprehension of the modulatory mechanisms, identification and characterization of the molecules involved in this process may assist in developing alternative economical therapies for treating inflammatory diseases, such as synthesis of analogues of $A$. suum that stimulate immunological tolerance.

\section{References}

Araújo CA, Perini A, Martins MA, Macedo MS, Macedo-Soares MF. PAS-1, an Ascaris suum protein, modulates allergic airway inflammation via CD8 ${ }^{+}$y $\delta T C R^{+}$and CD4+ CD25+ FoxP3+ T cells. Scand J Immunol 2010; 72(6): 491-503. http://dx.doi.org/10.1111/ j.1365-3083.2010.02465.x. PMid:21044123.

Buxbaum LU, Scott P. Interleukin 10- and Fcy receptor-deficient mice resolve Leishmania mexicana lesions. Infect Immun 2005; 73(4): 2101-2108. http://dx.doi.org/10.1128/IAl.73.4.2101-2108.2005. PMid:15784551.

Erhardt A, Biburger M, Papadopoulos T, Tiegs G. IL-10, regulatory T cells, and Kupffer cells mediate tolerance in concanavalin A-induced liver injury in mice. Hepatology 2007; 45(2): 475-485. http://dx.doi.org/10.1002/hep.21498. PMid:17256743.

Fairfax KC, Amiel E, King IL, Freitas TC, Mohrs M, Pearce EJ. IL-10R blockade during chronic schistosomiasis mansoni results in the loss of B cells from the liver and the development of severe pulmonary disease. PLoS Pathog 2012; 8(1): e1002490. http:// dx.doi.org/10.1371/journal.ppat.1002490. PMid:22291593.

Ferreira AP, Faquim ES, Abrahamsohn IA, Macedo MS. Immunization with Ascaris suum extract impairs T cell functions in mice. Cell Immunol 1995; 162(2): 202-210. http://dx.doi.org/10.1006/cimm.1995.1070. PMid:7743547.

Gazzinelli-Guimarães AC, Gazzinelli-Guimarães PH, Nogueira DS, Oliveira FMS, Barbosa FS, Amorim CCO, et al. IgG Induced by vaccination with Ascaris suum extracts is protective against infection. Front Immuno/ 2018; 9: 2535. http://dx.doi.org/10.3389/ fimmu.2018.02535. PMid:30473693.

Nascimento WC, Silva RP, Fernandes ES, Silva MC, Holanda GC, Santos PA, et al. Immunomodulation of liver injury by Ascaris suum extract in an experimental model of autoimmune hepatitis. Parasito/ Res 2014; 113(9): 3309-3317. http://dx.doi.org/10.1007/ s00436-014-3994-6. PMid:24951170.

Rolot M, Dewals BG. Macrophage activation and functions during helminth infection: recent advances from the laboratory mouse. J Immunol Res 2018; 2018: 2790627. http://dx.doi.org/10.1155/2018/2790627. PMid:30057915. 
Silva AS, Cavalcante LT, Faquim-Mauro EL, Macedo MS. Regulation of anaphylactic IgG1 antibody production by IL-4 and IL-10. Int Arch Allergy Immunol 2006; 141(1): 70-78. http://dx.doi.org/10.1159/000094256. PMid:16804329.

Souza VMO, Faquim-Mauro EL, Macedo MS. Extracts of Ascaris suum egg and adult worm share similar immunosuppressive properties. Braz J Med Biol Res 2002; 35(1): 81-89. http://dx.doi.org/10.1590/S0100-879X2002000100012. PMid:11743619.

Tiegs G, Hentschel J, Wendel AA. T cell-dependent experimental liver injury in mice inducible by concanavalin A.J Clin Invest 1992; 90(1): 196-203. http://dx.doi.org/10.1172/JCI115836. PMid:1634608.

Wei HX, Chuang YH, Li B, Wei H, Sun R, Moritoki Y, et al. CD4+ CD25+ Foxp3+ regulatory T cells protect against T cell-mediated fulminant hepatitis in a TGF-ß-dependent manner in mice. J Immunol 2008; 181(10): 7221-7229. http://dx.doi.org/10.4049/ jimmunol.181.10.7221. PMid:18981144.

Wei J, Versteeg L, Liu Z, Keegan B, Gazzinelli-Guimarães AC, Fujiwara RT, et al. Yeast-expressed recombinant As16 protects mice against Ascaris suum infection through induction of a Th2-skewed immune response. PLoS Neg/ Trop Dis 2017; 11(7): e0005769. http://dx.doi.org/10.1371/journal.pntd.0005769. PMid:28708895. 